INTERNATIONAL JOURNAL OF
ORGANIZATIONAL LEADERSHIP
ORGANIZATIONAL
IEADERSHIP

\title{
Progressive Convergent Definition and Conceptualization of Organizational Resilience: A Model Development
}

\author{
Eltigani Ahmed $^{1 *}$, James Kilika ${ }^{2}$, Clare Gakenia ${ }^{3}$ \\ ${ }^{1,3}$ School of Leadership, Business and Technology, Pan Africa Christian University, Nairobi, Kenya \\ ${ }^{2}$ School of Business, Kenyatta University, Nairobi, Kenya
}

\begin{abstract}
Keywords:

Organizational resilience,

Organizational leadership,

Ecosystem, Disruptive shocks,

Systematic review

\section{Received}

09 October 2021

Received in revised form

27 October 2021

Accepted

28 October 2021

*Correspondence:

eltigani.ali@students.

pacuniversity.ac.ke

This paper aims to examine how the construct of resilience is currently defined and propose a more comprehensive and unidirectional definition, conceptualization, and operationalization for the construct. We applied a rigorous systematic literature review in line with Preferred Reporting Items for Systematic Reviews and Meta-analyses (PRISMA) selection criteria covering historical currency, topical relevance, and publication appropriateness. We reviewed 1490 articles and publications on organizational resilience generated from a combination of academic databases and search engines. We identified the points of convergence and divergence in the definitions and discussed the implications for theorizing organizational resilience. The thematic descriptive extracted from the selected articles were cross-validated from comparable peer-reviewed papers included in this study. The article departed from common knowledge that organizational resilience is still evolving, and a unified definition is necessary to guide future scholarly works. We attempted to provide a current answer to the question, what is organizational resilience. We proposed that organizational resilience is the process and outcome of strategic preparedness for an adaptive response to disruptive shocks, capitalization on disruptive shocks, instinctive survival, positive transformation, and prosperity through disruptive shocks. We further proposed a conceptual model to illustrate our ideas. This article contributed to the ongoing debate on how organizational resilience should be defined and conceptualized using the most updated systematic review reporting framework.
\end{abstract}

CCIKD Publishing

Modern organizational ecosystem leadership is increasingly becoming an acronym for change leadership in an increasingly volatile, uncertain, complex, and ambiguous world (Duchene, 2017). Continuous change is a new normal where existential threats induced by exogenous 
shocks are diffuse and unpredictable, and organizational heritages are under constant and evolving stress (Mack et al., 2015). In this world, disruptive and accelerating shocks are multifaceted, sudden, and incomprehensible (Bakshi, 2017; Kok \& Van den Heuvel, 2018).

Several landmark events have happened in the last two decades that support the above argument. The September 11 terror attack on American soil degenerated into a reactive trail of events that largely shaped the world of business today (Smith \& Zeigler, 2017). In 2004, subContinental Southeast Asia was hit by a devastating earthquake that left a trail of disruption in at least 15 countries (Lund \& Blaikie, 2013). In 2007, a degenerative financial crisis resulted in a global economic recession that was estimated to have eroded US\$19 trillion in worldwide wealth and caused the loss of 10 million jobs (Njiforti, 2015). In December 2019, the virus detected in Wuhan quickly escalated into a global pandemic that has already claimed millions of lives and caused unprecedented economic disruption worldwide (Adolph et al., 2021; Di Gennaro et al., 2020). One would enumerate narratives of shocks of systemic proportions, but one thing is clear, disruptions will continue to occur, and organizations will continue to adapt to shocks (Chakrabarti, 2015). However, according to Palmi et al. (2018), a differentiating factor lies in how organizations anticipate, react, and adapt to shocks.

There has been a growing interest in organizational resilience research to provide a body of knowledge that executives can draw from to respond effectively to exogenous shocks (Al Balushi, 2020; Doğantan \& Kozak, 2019; Pariès, 2017; Wishart, 2018). An essential first step in this direction is the sense-making of the concept of organizational resilience. A quick incursion reveals that organizational resilience literature recognizes an expanded definitional spectrum for the construct of resilience that ranges from narrow unidimensional attribution to broader multidimensional ideas (Filimonau, \& De Coteau, 2019; Ruiz-Martin et al., 2017). The absence of a unified definition impacts the construct's conceptualization and measurement validity and, consequently, affects organizational resilience research outcomes (Padar \& Pataki, 2018; Ruiz-Martin, López-Paredes, \& Wainer, 2018).

Previous research interests in unraveling the meaning and measurement of organizational resilience have revealed a vast array of themes that provide a rich and expansive repository of resources (Andersson et al., 2019; Ince et al., 2017; Yang, 2019). However, in defining organizational resilience, these studies have framed adversity narrowly as a threat, in effect deflecting focus away from the potential in organizational resilience as the utilization of adversity as an opportunity to orchestrate transformative growth. One exception is the work of Barasa, Mbau, and Gilson (2018), but their study was limited in scope to the resilience of health systems. McCarthy, Collard, and Johnson (2017) also advanced the notion of adversity as an opportunity, but their review was limited to the banking and automotive industries. Other predecessors (Gorzeń-Mitka, 2016; Ma et al., 2018; Padar \& Pataki, 2018; Ruiz-Martin et al., 2017; Ruiz-Martin et al., 2018) conducted a review of extant literature rather than a systematic review. The lack of methodological rigor in the literature review exposes the ensuing conceptualization of organizational resilience to the risk of bias (Page et al., 2021).

This article examines how organizational resilience is currently defined and proposes a unidirectional conceptualization, measurement, and application definition for the construct. In this endeavor, the article examines scholarly literature on organizational resilience research to map out its various extant definitions, conceptualizations, and operationalization. It identifies the points of convergence and divergence in the definitions and discusses the implications for 
theorizing organizational resilience. It provides a current answer to the question, what is organizational resilience? It departs from a common discourse that organizational resilience as a concept is still evolving, and a unified definition is necessary to guide future scholarly works. Finally, the article aims to contribute to the ongoing debate on how organizational resilience is defined and conceptualized through a systematic review.

\section{Method}

A systematic review methodology was deployed to achieve three objectives. First, to synthesize and critique organizational resilience literature. Second, to provide an overall account of the extent, nature, and quality of literary production concerning the definition of organizational resilience. Third, highlight the inherent gap between what is known and not known (Siddaway, Wood, \& Hedges, 2019). This process was undertaken in line with PRISMA inclusion and exclusion criteria to enhance transparency and reproducibility (Misra \& Agarwal, 2018; Selcuk, 2019). The PRISMA statement 2020, first published in 2009 and subsequently in 2021, entails a 27-item checklist and a four-phased flowchart (Snyder, 2019) that has since been updated and enhanced (Page et al., 2021). In conformity with the PRISMA checklist, articles were prescreened to ensure a structured summary, a rationale in the introduction and background, and an explicit statement of the problem. The article eligibility criteria and information sources, along with the limits, were also set.

The article reviewed multiple business and social science databases, search engines, opensource journals, and unpublished theses and dissertations in various online repositories. Specifically, a search was performed on Crossref, Google Scholar, and academic repositories using Harzing's (2010) Publish or Perish software and advanced google search tool. The inclusion criteria covered historical currency, topical relevance, and publication appropriateness (Siddaway et al., 2019). Therefore, studies conducted earlier than the year 2015 were excluded from the review. A database query was performed using a combination of keyword searches, including "organizational resilience/sustainability", "firm resilience/sustainability", "company resilience/sustainability", "enterprise resilience/sustainability", and "business resilience/sustainability". These keywords needed to appear in the title and/or abstract. The titles and abstracts were first screened for eligibility; then, the full texts were reviewed for further eligibility. A total number of 1490 articles were initially screened using this keyword search and combination method. The list was then narrowed down to 144 articles eligible for abstract skimming. The abstract skimming processes resulted in 48 articles shortlisted for abstract reading. A final filtering method based on thematic relevance, methodology, contextual balance, and findings resulted in a final list of 30 articles retained for the systematic review. The iterative and evaluative process of the interpretive construct identification method applied in this paper entailed a systematic evaluation of detached theoretical propositions to delineate sense-making patterns to advance distinct theoretical propositions (Danziger \& Kampf, 2020). This approach is anchored on extractive-inductive reasoning and has been widely adopted in theory development (Gephart, 2018; Panhwar et al., 2017; Serhun, 2013). 


\section{Findings}

The search and screening process shortlisted 30 studies, as illustrated in Figure 1. In maintaining PRISMA rules, the details and characteristics of studies screened were presented in Table 1, and the main findings were summarized and the results interpreted and discussed accordingly (Misra \& Agarwal, 2018).

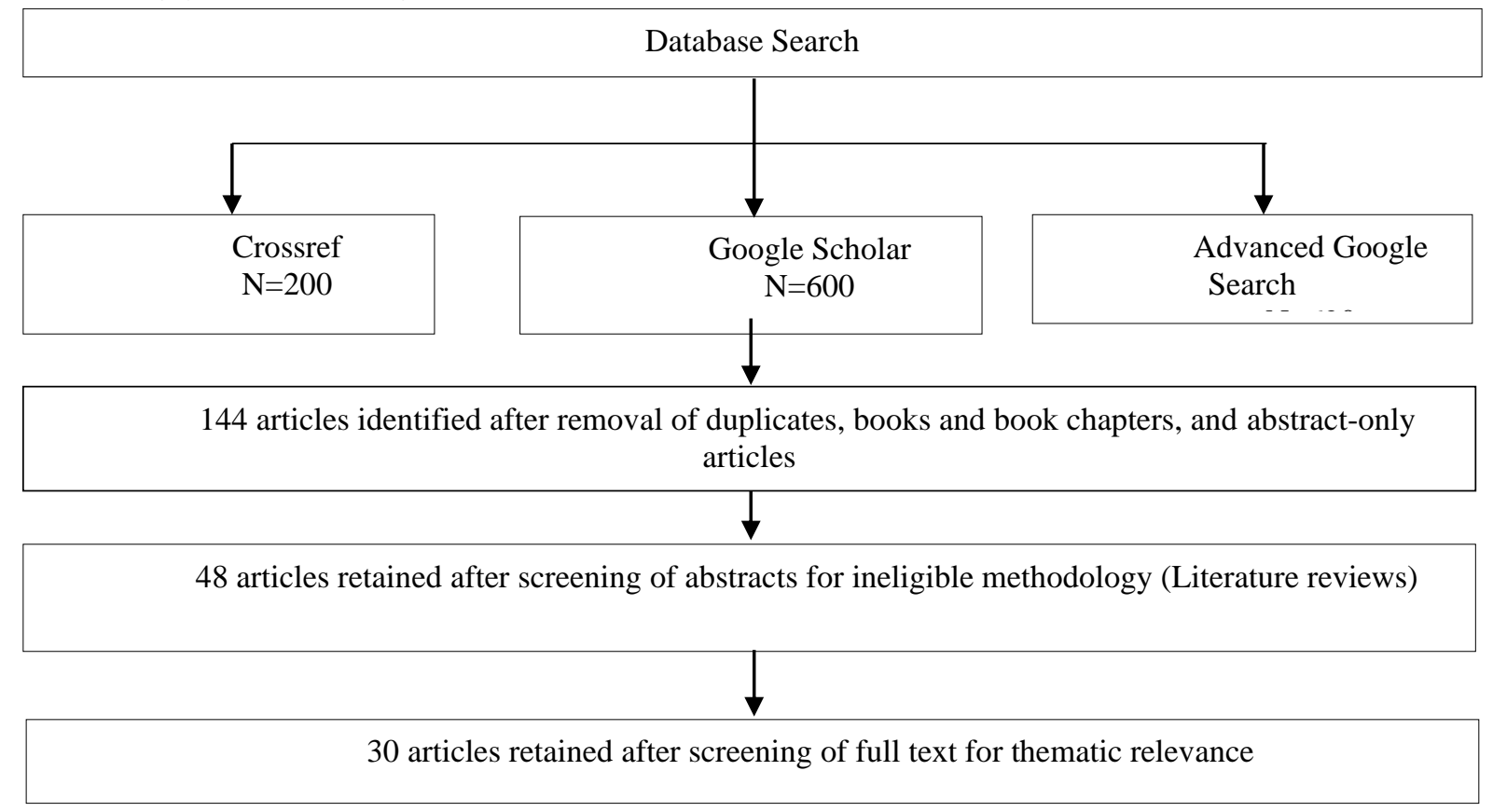

Figure 1. Article selection flowchart

\section{Demographic Characteristics of the Screened Studies}

Over two-thirds of the studies were undertaken in the Global North, characterized by developed resilience resources, infrastructure, and support systems (Edwin \& Okpara, 2015). The remaining studies were conducted in the Global South, specifically in Asia and Africa. It has also been observed that most of the studies' scenes were remarkably diverse and spanned from natural disasters to human-made disruptions. Furthermore, the organizations were from various sectors and included both public and private establishments. In terms of design, most of the studies used survey design and questionnaire instruments, while statistical analyses were primarily performed through regression and structural equation modeling. The studies reviewed were deemed to have methodological rigor, which reduced exposure to the risk of bias. A comprehensive review result is reported in Table 1. 
Table 1

Characteristics of Studies Included in the Systematic Review

\begin{tabular}{|c|c|c|c|c|c|c|}
\hline Publications & Aims & Context & Scope & $\begin{array}{l}\text { Research } \\
\text { design }\end{array}$ & $\begin{array}{l}\text { Data collection } \\
\text { method }\end{array}$ & $\begin{array}{l}\text { Data analysis } \\
\text { method }\end{array}$ \\
\hline $\begin{array}{l}\text { Essuman et al. } \\
(2020)\end{array}$ & $\begin{array}{l}\text { investigating the } \\
\text { relationship between } \\
\text { operational resilience and } \\
\text { efficiency under } \\
\text { operational disruption }\end{array}$ & $\begin{array}{l}\text { Ghanaian } \\
\text { industries }\end{array}$ & $\begin{array}{l}\text { Natural and human- } \\
\text { made disasters }\end{array}$ & Survey & Questionnaires & SEM \\
\hline $\begin{array}{l}\text { Andersson et al. } \\
(2019)\end{array}$ & $\begin{array}{l}\text { Describing and explaining } \\
\text { how organizational } \\
\text { structures can build } \\
\text { organizational resilience }\end{array}$ & $\begin{array}{l}\text { UK banking } \\
\text { sector }\end{array}$ & $\begin{array}{l}\text { Dynamic } \\
\text { environmental } \\
\text { contexts }\end{array}$ & $\begin{array}{l}\text { Longitudinal } \\
\text { qualitative }\end{array}$ & Interviews & qualitative \\
\hline Al Balushi (2020) & $\begin{array}{l}\text { Investigating the } \\
\text { relationship between } \\
\text { quality management and } \\
\text { resilience }\end{array}$ & $\begin{array}{l}\text { Oman's } \\
\text { education } \\
\text { sector }\end{array}$ & $\begin{array}{l}\text { Natural disasters and } \\
\text { human-made crises }\end{array}$ & Qualitative & $\begin{array}{l}\text { Semi- } \\
\text { structured } \\
\text { interviews }\end{array}$ & Thematic \\
\hline $\begin{array}{l}\text { Suryaningtyas et al. } \\
\text { (2019) }\end{array}$ & $\begin{array}{l}\text { Investigating the } \\
\text { relationship between } \\
\text { resilience and performance } \\
\text { resilient, mediating } \\
\text { leadership and } \\
\text { organizational culture }\end{array}$ & $\begin{array}{l}\text { Indonesia } \\
\text { Hospitality } \\
\text { sector }\end{array}$ & $\begin{array}{l}\text { Cross-sectional data } \\
\text { based on self-reports }\end{array}$ & Quantitative & Questionnaires & Quantitative \\
\hline $\begin{array}{l}\text { Filimonau \& } \\
\text { De Coteau (2019) }\end{array}$ & $\begin{array}{l}\text { To evaluate tourism } \\
\text { resilience in Grenada }\end{array}$ & $\begin{array}{l}\text { Grenada } \\
\text { tourism sector }\end{array}$ & $\begin{array}{l}\text { Natural disasters } \\
\text { (hurricanes, floods, } \\
\text { earthquakes, and } \\
\text { tsunami) }\end{array}$ & Exploratory & $\begin{array}{l}\text { Semi- } \\
\text { structured } \\
\text { interviews }\end{array}$ & Thematic \\
\hline Mukabi et al. (2019) & $\begin{array}{l}\text { Investigating crisis } \\
\text { management strategies for } \\
\text { the attainment of business } \\
\text { continuity best practices }\end{array}$ & $\begin{array}{l}\text { Kenya } \\
\text { telecom sector }\end{array}$ & $\begin{array}{l}\text { Specialized staff } \\
\text { turnover, } \\
\text { technological } \\
\text { changes, and } \\
\text { incidences }\end{array}$ & Descriptive & $\begin{array}{l}\text { Semi- } \\
\text { structured } \\
\text { questionnaires }\end{array}$ & Regression \\
\hline Alibašić (2018) & $\begin{array}{l}\text { Examining the role officials } \\
\text { have in embedding } \\
\text { sustainability within cities }\end{array}$ & $\begin{array}{l}\text { United States } \\
\text { public sector }\end{array}$ & $\begin{array}{l}\text { Economic, social, } \\
\text { and environmental } \\
\text { forces }\end{array}$ & Qualitative & $\begin{array}{l}\text { In-person } \\
\text { interviews }\end{array}$ & Thematic \\
\hline Patriarca et al. (2018) & $\begin{array}{l}\text { Creating a structured } \\
\text { framework to define a } \\
\text { resilience profile at } \\
\text { different levels of } \\
\text { abstraction }\end{array}$ & $\begin{array}{l}\text { Central } \\
\text { Europe } \\
\text { healthcare }\end{array}$ & $\begin{array}{l}\text { Resilience of } \\
\text { systems }\end{array}$ & $\begin{array}{l}\text { A semi- } \\
\text { quantitative } \\
\text { analytical }\end{array}$ & $\begin{array}{l}\text { Document } \\
\text { analysis }\end{array}$ & $\begin{array}{l}\text { Resilience } \\
\text { analysis grid }\end{array}$ \\
\hline Menéndez (2018) & $\begin{array}{l}\text { Reviewing how learning } \\
\text { sustains organizations in } \\
\text { crisis and breakdown }\end{array}$ & $\begin{array}{l}\text { United States } \\
\text { oil and gas } \\
\text { industry } \\
\end{array}$ & 2008 financial crisis & $\begin{array}{l}\text { Book and } \\
\text { media } \\
\text { review }\end{array}$ & $\begin{array}{l}\text { Document } \\
\text { analysis }\end{array}$ & Thematic \\
\hline Burnard et al. (2018) & $\begin{array}{l}\text { Exploring the } \\
\text { organizational processes at } \\
\text { the onset of disruptions and } \\
\text { the factors that determine } \\
\text { different configurations of } \\
\text { responses }\end{array}$ & $\begin{array}{l}\text { United } \\
\text { Kingdom } \\
\text { power } \\
\text { industry }\end{array}$ & $\begin{array}{l}\text { Disruptions and } \\
\text { crisis management } \\
\text { of critical } \\
\text { infrastructure in } \\
\text { high-risk } \\
\text { environments }\end{array}$ & $\begin{array}{l}\text { Multiple } \\
\text { case study }\end{array}$ & Interviews & Thematic \\
\hline Jia (2018) & $\begin{array}{l}\text { To empirically test the } \\
\text { relationship between social } \\
\text { capital and organizational } \\
\text { resilience }\end{array}$ & $\begin{array}{l}\text { China social } \\
\text { infrastructure }\end{array}$ & $\begin{array}{l}\text { Large companies } \\
\text { affected by the } 2008 \\
\text { Sichuan earthquake }\end{array}$ & Survey & Questionnaires & $\begin{array}{l}\text { Partial least } \\
\text { squares }\end{array}$ \\
\hline Palmi et al. (2018) & $\begin{array}{l}\text { Assessing the role of } \\
\text { organizational resilience as } \\
\text { an attitude, depending on } \\
\text { the adoption of corporate } \\
\text { governance, environmental } \\
\text { and social practices }\end{array}$ & $\begin{array}{l}\text { United States } \\
\text { listed } \\
\text { companies in } \\
\text { diverse sectors }\end{array}$ & 2008 financial crisis & Quantitative & $\begin{array}{l}\text { Document } \\
\text { analysis }\end{array}$ & $\begin{array}{l}\text { Panel data } \\
\text { analysis }\end{array}$ \\
\hline Prayag et al. (2018) & $\begin{array}{l}\text { Investigating the } \\
\text { relationship between } \\
\text { organizational resilience } \\
\text { and financial performance }\end{array}$ & $\begin{array}{l}\text { New Zealand } \\
\text { Tourism } \\
\text { sector }\end{array}$ & Earthquake & Survey & Questionnaires & Regression \\
\hline $\begin{array}{l}\text { Pulungan et al. } \\
\text { (2018) }\end{array}$ & $\begin{array}{l}\text { Investigating the influence } \\
\text { of firm strategy and } \\
\text { organizational resilience to } \\
\text { technology orientation }\end{array}$ & $\begin{array}{l}\text { Indonesian } \\
\text { coal mining } \\
\text { sector }\end{array}$ & $\begin{array}{l}\text { Political, social, and } \\
\text { cultural changes }\end{array}$ & Explanatory & Questionnaires & SEM \\
\hline Scholarone (2018) & $\begin{array}{l}\text { Analyzing the role } \\
\text { corporate social } \\
\text { responsibility plays toward } \\
\text { employees in the promotion } \\
\text { of resilience at work. }\end{array}$ & $\begin{array}{l}\text { Spanish } \\
\text { companies } \\
\text { from diverse } \\
\text { sectors }\end{array}$ & $\begin{array}{l}\text { Dynamic market } \\
\text { environment }\end{array}$ & Survey & Questionnaires & SEM \\
\hline
\end{tabular}




\begin{tabular}{|c|c|c|c|c|c|c|}
\hline Publications & Aims & Context & Scope & $\begin{array}{l}\text { Research } \\
\text { design }\end{array}$ & $\begin{array}{l}\text { Data collection } \\
\text { method }\end{array}$ & $\begin{array}{l}\text { Data analysis } \\
\text { method }\end{array}$ \\
\hline Ochieng (2018) & $\begin{array}{l}\text { To establish the influence } \\
\text { of supply chain resilience } \\
\text { on organizational } \\
\text { performance }\end{array}$ & $\begin{array}{l}\text { Kenya } \\
\text { pharmaceutica } \\
1 \text { sector }\end{array}$ & $\begin{array}{l}\text { Globalization, } \\
\text { changes in } \\
\text { technology, and } \\
\text { intense competition } \\
\text { in a dynamic } \\
\text { economic } \\
\text { environment }\end{array}$ & Descriptive & Questionnaires & Descriptive \\
\hline Acosta et al. (2017) & $\begin{array}{l}\text { How to integrate progress } \\
\text { in parallel streams of } \\
\text { individual and community } \\
\text { resilience research }\end{array}$ & $\begin{array}{l}\text { North } \\
\text { America and } \\
\text { Europe across } \\
\text { sectors }\end{array}$ & $\begin{array}{l}\text { Stressors at the } \\
\text { individual, } \\
\text { household, and } \\
\text { community levels }\end{array}$ & Round-table & Focus Group & Thematic \\
\hline $\begin{array}{l}\text { Besuner \& } \\
\text { Bewley (2017) }\end{array}$ & $\begin{array}{l}\text { Exploring whether self- } \\
\text { efficacy, psychological } \\
\text { empowerment, and } \\
\text { personal resilience predict } \\
\text { organizational resilience }\end{array}$ & $\begin{array}{l}\text { Academic and } \\
\text { healthcare } \\
\text { systems }\end{array}$ & Unspecified & Correlational & Questionnaires & Correlation \\
\hline Brown et al. (2017) & $\begin{array}{l}\text { To present a method for } \\
\text { assessing the organizational } \\
\text { resilience of critical } \\
\text { infrastructure organizations }\end{array}$ & $\begin{array}{l}\text { New Zealand } \\
\text { critical } \\
\text { infrastructure }\end{array}$ & Unspecified & $\begin{array}{l}\text { Cross- } \\
\text { sectional } \\
\text { survey }\end{array}$ & Questionnaires & Quantitative \\
\hline $\begin{array}{l}\text { Fukofuka et al. } \\
\text { (2017) }\end{array}$ & $\begin{array}{l}\text { Examining the relationship } \\
\text { between organizational } \\
\text { resilience and the following } \\
\text { predictors: openness, trust, } \\
\text { authenticity, and proaction }\end{array}$ & $\begin{array}{l}\text { Philippine } \\
\text { education } \\
\text { sector }\end{array}$ & $\begin{array}{l}\text { Shocks due to } \\
\text { change in the } \\
\text { education system }\end{array}$ & $\begin{array}{l}\text { Cross- } \\
\text { sectional }\end{array}$ & Questionnaires & Regression \\
\hline $\begin{array}{l}\text { Rozensky et al. } \\
\text { (2016) }\end{array}$ & $\begin{array}{l}\text { To present organizational } \\
\text { trauma theory as an } \\
\text { organizing model for } \\
\text { conceptualizing the impact } \\
\text { of organizational stressors }\end{array}$ & $\begin{array}{l}\text { United States, } \\
\text { \& European } \\
\text { Union }\end{array}$ & Various crises & $\begin{array}{l}\text { Historical } \\
\text { review }\end{array}$ & $\begin{array}{l}\text { Document } \\
\text { analysis }\end{array}$ & Qualitative \\
\hline Campos (2016) & $\begin{array}{l}\text { To determine the } \\
\text { dimensions of business } \\
\text { resilience in the context of } \\
\text { post-disaster recovery } \\
\text { among business } \\
\text { establishments in Davao } \\
\text { City }\end{array}$ & $\begin{array}{l}\text { Southern } \\
\text { Philippines } \\
\text { business }\end{array}$ & $\begin{array}{l}\text { Businesses disrupted } \\
\text { by flash floods in } \\
2011 \text { and focus on } \\
\text { post-disaster } \\
\text { recovery }\end{array}$ & Mixed & $\begin{array}{l}\text { Interviews and } \\
\text { questionnaires }\end{array}$ & Triangulation \\
\hline $\begin{array}{l}\text { Capano \& Woo } \\
(2017)\end{array}$ & $\begin{array}{l}\text { To review definitions of } \\
\text { resilience concepts and the } \\
\text { theoretical and empirical } \\
\text { challenges presented by } \\
\text { policy process and policy } \\
\text { design }\end{array}$ & $\begin{array}{l}\text { US and } \\
\text { Europe Public } \\
\text { sector }\end{array}$ & Public policy & Qualitative & $\begin{array}{l}\text { Document } \\
\text { analysis }\end{array}$ & Thematic \\
\hline Chen (2016) & $\begin{array}{l}\text { To clarify a five-factor } \\
\text { model for organizational } \\
\text { resilience of R\&D teams }\end{array}$ & $\begin{array}{l}\text { China, Higher } \\
\text { education } \\
\text { sector } \\
\end{array}$ & Competitive risks & Mixed & $\begin{array}{l}\text { Interviews and } \\
\text { questionnaires }\end{array}$ & Triangulation \\
\hline $\begin{array}{l}\text { Georgios Christos } \\
(2017)\end{array}$ & $\begin{array}{l}\text { To explore factors that } \\
\text { allow a corporation to } \\
\text { survive and thrive despite } \\
\text { pressures from the external } \\
\text { environment }\end{array}$ & $\begin{array}{l}\text { Greek tourism } \\
\text { sector }\end{array}$ & $\begin{array}{l}\text { Greek post-crisis } \\
\text { economic } \\
\text { environment }\end{array}$ & Qualitative & Interviews & Thematic \\
\hline $\begin{array}{l}\text { Zehir \& Narcikara } \\
\text { (2016) }\end{array}$ & $\begin{array}{l}\text { Investigating the effects of } \\
\text { resilience on productivity } \\
\text { under authentic leadership }\end{array}$ & $\begin{array}{l}\text { Turkish } \\
\text { manufacturing }\end{array}$ & $\begin{array}{l}\text { Terrorism, the threat } \\
\text { of war, and } \\
\text { recession }\end{array}$ & Survey & Questionnaires & $\begin{array}{l}\text { Path analysis } \\
\text { and SEM }\end{array}$ \\
\hline $\begin{array}{l}\text { Edwin \& Okpara } \\
(2015)\end{array}$ & $\begin{array}{l}\text { To establish the influence } \\
\text { of supply chain resilience } \\
\text { on organizational } \\
\text { performance of } \\
\text { manufacturing } \\
\text { pharmaceutical companies } \\
\text { in Nairobi }\end{array}$ & $\begin{array}{l}\text { Kenya } \\
\text { pharmaceutica } \\
\text { l sector }\end{array}$ & $\begin{array}{l}\text { Globalization, } \\
\text { changes in } \\
\text { technology, } \\
\text { competition, and } \\
\text { dynamic economic } \\
\text { environment }\end{array}$ & Descriptive & Questionnaire & Quantitative \\
\hline Chu (2015) & $\begin{array}{l}\text { To examine the } \\
\text { multidimensionality of } \\
\text { resilience capabilities of } \\
\text { SMEs in the face of } \\
\text { turbulent environments }\end{array}$ & $\begin{array}{l}\text { Hong Kong } \\
\text { SMEs }\end{array}$ & $\begin{array}{l}\text { Spillover from the } \\
\text { tsunami and } \\
\text { associated nuclear } \\
\text { meltdown that hit } \\
\text { Japan }\end{array}$ & Mixed & $\begin{array}{l}\text { Interviews and } \\
\text { Questionnaires }\end{array}$ & Triangulation \\
\hline Collins (2015) & $\begin{array}{l}\text { To elaborate on what } \\
\text { contributes to resilience in } \\
\text { firms }\end{array}$ & $\begin{array}{l}\text { New Zealand } \\
\text { Manufacturing }\end{array}$ & $\begin{array}{l}\text { Global Financial } \\
\text { Crisis }\end{array}$ & Mixed & $\begin{array}{l}\text { Semi- } \\
\text { structured } \\
\text { interviews } \\
\end{array}$ & Triangulation \\
\hline $\begin{array}{l}\text { Witmer \& Mellinger, } \\
2016\end{array}$ & $\begin{array}{l}\text { identifying organizational } \\
\text { characteristics of healthcare } \\
\text { organizations }\end{array}$ & $\begin{array}{l}\text { United States } \\
\text { healthcare }\end{array}$ & $\begin{array}{l}\text { Dynamic } \\
\text { organizational } \\
\text { environment }\end{array}$ & $\begin{array}{l}\text { Multiple } \\
\text { case study }\end{array}$ & $\begin{array}{l}\text { Interviews and } \\
\text { focus groups }\end{array}$ & $\begin{array}{l}\text { Content } \\
\text { analysis }\end{array}$ \\
\hline
\end{tabular}




\section{Current Understanding of the Organizational Resilience}

In line with the current definition of resilience, the screened studies generated seven thematic descriptors used to define organizational resilience in the study sample. The thematic descriptors are anticipatory ability and planning, response to disruption, recovery from disruption, survival ability, shock absorption, positive adaptation, and capitalizing on disruption. The descriptors are condensed in a one-word phrase format for reporting convenience, noting that each descriptor corresponds to several synonyms in the original texts. Table 2 reveals that over two-thirds of the studies defined organizational resilience using only one or two thematic descriptors. In addition, none of the studies combined all the seven thematic descriptors in defining organizational resilience. These thematic descriptors and their frequencies are reported in Table 2.

Furthermore, it is evident from Table 2 that there is no consensus among the 30 studies reviewed on a single thematic describer. Table 2 indicates that most studies converged toward the notion that organizational resilience refers to positive adaptation, which scored 15 hits, followed by shock absorption and recovery from shocks, each with ten hits. The sample also tilted toward relative convergence in depicting organizational resilience as the anticipatory ability and planning and/or response to disruption, with nine hits each. However, a few studies (7 out of 30) defined organizational resilience as capitalizing on disruption, and only two studies present organizational resilience as an ability to survive.

Table 2

Thematic Definitions of Organizational Resilience

\begin{tabular}{|c|c|c|c|c|c|c|c|c|}
\hline Author (s) \& Date & $\begin{array}{c}\text { Positive } \\
\text { adaptation }\end{array}$ & $\begin{array}{c}\text { Shock } \\
\text { absorption }\end{array}$ & $\begin{array}{l}\text { Disruption } \\
\text { recovery }\end{array}$ & $\begin{array}{l}\text { Anticipatory } \\
\text { and planning }\end{array}$ & $\begin{array}{l}\text { Response to } \\
\text { disruption }\end{array}$ & $\begin{array}{c}\text { Capitalizing } \\
\text { on } \\
\text { disruption }\end{array}$ & $\begin{array}{l}\text { Survival } \\
\text { ability }\end{array}$ & $\begin{array}{l}\text { Total } \\
\text { count }\end{array}$ \\
\hline $\begin{array}{l}\text { Essuman et al. } \\
(2020)\end{array}$ & & $\checkmark$ & $\checkmark$ & & & & & 2 \\
\hline $\begin{array}{l}\text { Andersson et al. } \\
\text { (2019) }\end{array}$ & & & & $\checkmark$ & $\checkmark$ & & & 2 \\
\hline Al Balushi (2020) & $\checkmark$ & & & & & $\checkmark$ & & 2 \\
\hline $\begin{array}{l}\text { Suryaningtyas et } \\
\text { al. (2019) }\end{array}$ & $\checkmark$ & & & $\checkmark$ & $\checkmark$ & $\checkmark$ & $\checkmark$ & 5 \\
\hline $\begin{array}{l}\text { Filimonau \& De } \\
\text { Coteau (2019) }\end{array}$ & $\checkmark$ & & & $\checkmark$ & $\checkmark$ & $\checkmark$ & & 4 \\
\hline $\begin{array}{l}\text { Mukabi et al. } \\
(2019)\end{array}$ & & & $\checkmark$ & & & & & 1 \\
\hline Alibašić (2018) & $\checkmark$ & & & & & & & 1 \\
\hline $\begin{array}{l}\text { Patriarca et al. } \\
\text { (2018) }\end{array}$ & & $\checkmark$ & $\checkmark$ & & & & & 2 \\
\hline Menéndez (2018) & & $\checkmark$ & & & $\checkmark$ & $\checkmark$ & & 3 \\
\hline $\begin{array}{l}\text { Burnard et al. } \\
(2018)\end{array}$ & $\checkmark$ & & & $\checkmark$ & & & & 2 \\
\hline Jia (2018) & & & $\checkmark$ & $\checkmark$ & $\checkmark$ & & & 2 \\
\hline Palmi et al. (2018) & $\checkmark$ & & & & & & & 1 \\
\hline $\begin{array}{l}\text { Prayag et al. } \\
(2018)\end{array}$ & & $\checkmark$ & & & & & $\checkmark$ & 2 \\
\hline $\begin{array}{l}\text { Pulungan et al. } \\
(2018)\end{array}$ & & $\checkmark$ & & & & & & 1 \\
\hline Scholarone (2018) & $\checkmark$ & & & & $\checkmark$ & $\checkmark$ & & 3 \\
\hline Ochieng (2018) & & $\checkmark$ & $\checkmark$ & $\checkmark$ & $\checkmark$ & & & 4 \\
\hline $\begin{array}{l}\text { Acosta et al. } \\
(2017)\end{array}$ & $\checkmark$ & & & $\checkmark$ & $\checkmark$ & & & 3 \\
\hline $\begin{array}{l}\text { Besuner \& Bewley } \\
(2017)\end{array}$ & $\checkmark$ & & & & & & & 1 \\
\hline Brown et al. (2017) & $\checkmark$ & & & $\checkmark$ & & $\checkmark$ & & 3 \\
\hline $\begin{array}{l}\text { Fukofuka et al. } \\
(2017)\end{array}$ & & $\checkmark$ & & & & & & 1 \\
\hline $\begin{array}{l}\text { Rozensky et al. } \\
\text { (2016) }\end{array}$ & $\checkmark$ & & $\checkmark$ & $\checkmark$ & $\checkmark$ & & & 4 \\
\hline Campos (2016) & & & $\checkmark$ & & & & & 1 \\
\hline
\end{tabular}




\begin{tabular}{|l|c|c|c|c|c|c|c|c|}
\hline $\begin{array}{l}\text { Capano \& Woo } \\
(2017)\end{array}$ & & & $\checkmark$ & & & & & 1 \\
\hline Chen (2016) & $\checkmark$ & & & & & & & \\
\hline $\begin{array}{l}\text { Georgios Christos } \\
(2017)\end{array}$ & & $\checkmark$ & $\checkmark$ & & & & & 2 \\
\hline $\begin{array}{l}\text { Zehir \& Narcikara } \\
(2016)\end{array}$ & & $\checkmark$ & $\checkmark$ & & & & & 2 \\
\hline $\begin{array}{l}\text { Edwin \& Okpara } \\
(2015)\end{array}$ & $\checkmark$ & & & & & & & 1 \\
\hline Chu (2015) & $\checkmark$ & & & $\checkmark$ & & & & 2 \\
\hline Collins (2015) & $\checkmark$ & $\checkmark$ & & & & & & 1 \\
\hline $\begin{array}{l}\text { Witmer \& } \\
\text { Mellinger, 2016 }\end{array}$ & $\checkmark$ & & & & & $\checkmark$ & & 2 \\
\hline Total count & 15 & 10 & 10 & 9 & 9 & 7 & 2 & 62 \\
\hline
\end{tabular}

\section{A Case for a Progressive Convergent Definition}

We present a case for a convergent unified definition of organizational resilience construct based on our observation that the separate thematic descriptors tilt toward a progressive thematic convergence with an increased number of observations. For instance, Figure 2 summarizes cumulative frequencies of the screened studies and shows that $24 \%$ of the studies contain 15 thematic frequencies, $40 \%$ contain 25 cumulative frequencies, $56 \%$ contain 35 cumulative frequencies, $71 \%$ contain 44 cumulative frequencies, $85 \%$ contain 53 cumulative frequencies, $97 \%$ contain 60 cumulative frequencies, and $100 \%$ contain all the cumulative frequencies.

Ostensibly, there is an element of abstractedness in the sample size, and a question might arise about what would happen if the sample increased beyond the current threshold? Obviously, the magnitude of aggregation will change, but the underlying concept will stand. Intuitively, this aggregation around a thematic convergence is made possible due to the underlying dynamic nature of the construct that permits its temporal delineation into predisruption, within-disruption, and post-disruption (see Figure 3). This progressiveness stipulates the idea of the progressive unidirectional definition and conceptualization. This is illustrated in Figure 2 through the cumulative frequency outlay.

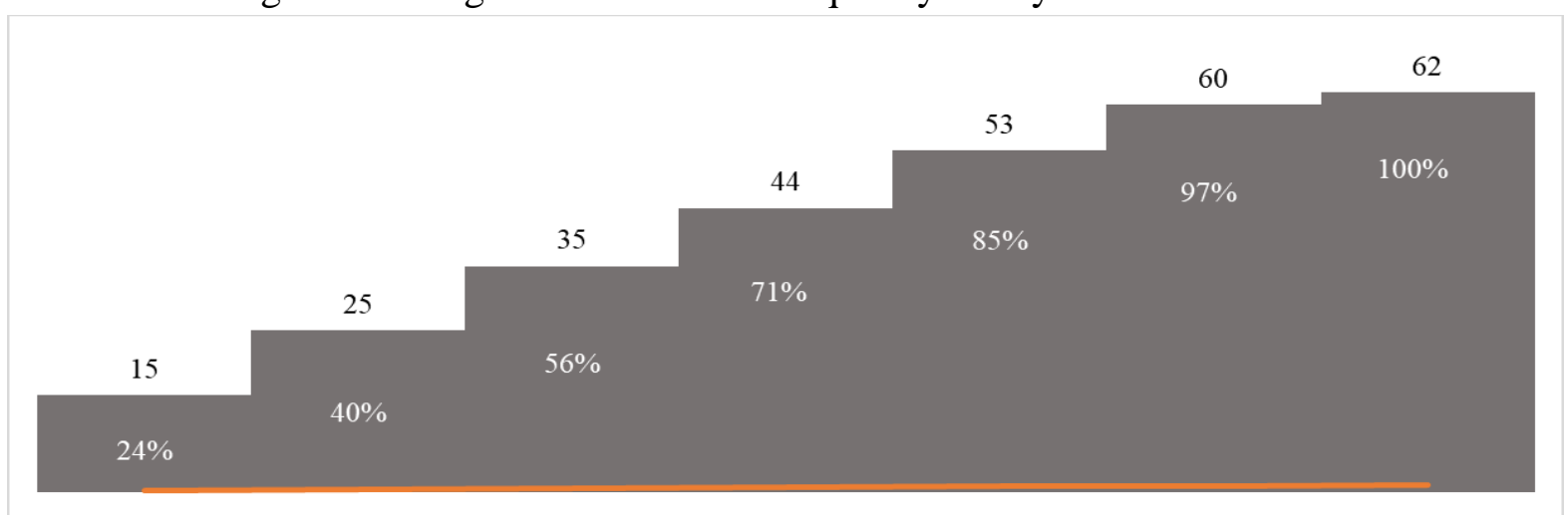

Figure 2. Thematic cumulative distribution graph

These findings present an optimistic trend that a unidirectional definition of the construct may be attainable at some point. Before a unified definition is proposed, attention is first drawn to how the studies dimensionalized, conceptualized, and operationalized organizational resilience. 


\section{Organizational Resilience Dimensions}

A synthesis of the conceptual literature on organization resilience converges around nine dimensions classified into pre-crisis, within-crisis, and post-crisis resilience, as detailed in Error! Reference source not found.Figure 3.

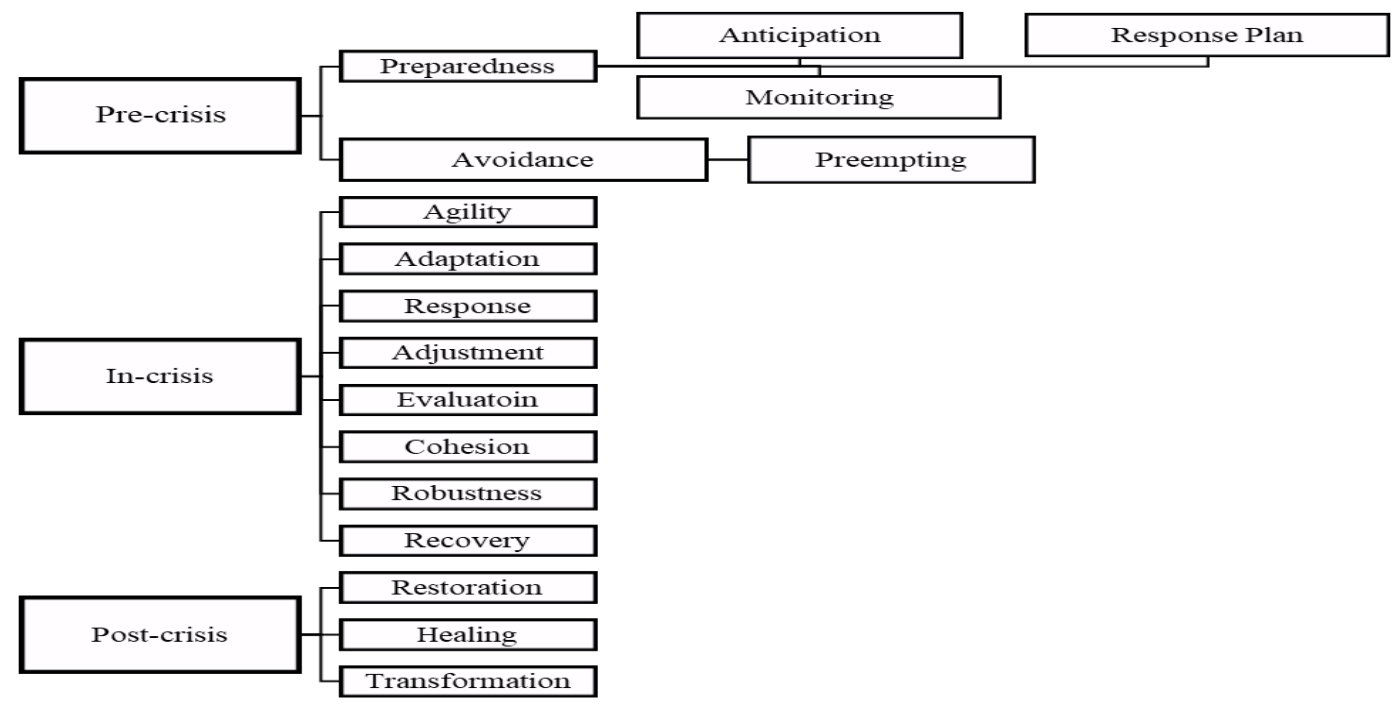

Figure 3. Sequencing and dimensions of resilience

Pre-crisis resilience is represented by preparedness and avoidance. Preparedness is a composite dimension comprising of anticipation (Sawyerr \& Harrison, 2019), monitoring and sensing potential disruptions (Yang, 2019), and putting in place a response plan (Barasa et al., 2018). Crisis avoidance is the ability to pre-empt a potential crisis (Ma et al., 2018).

Within-crisis, four complementary dimensions indicate organizational resilience. These dimensions include agility or capacity to take action rapidly (Andersson et al., 2019), adaptation or activation of resilience tools (Burnard et al., 2018), response to changing conditions (Holbeche, 2015), adjustment (Barasa et al., 2018), evaluation, cohesion, meaning the maintenance of harmony among employees, robustness, denoting capacity to withstand, and recover (Capano \& Woo, 2017).

The dimensions related to post-crisis resilience include normalcy restoration (Capano \& Woo, 2017), emotional healing (Rozensky et al., 2016), transformation, and prosperity (Suryaningtyas et al., 2019).

\section{Toward Conceptualization of Organizational Resilience}

The findings related to the current conceptualization and operationalization of organizational resilience are presented in Table 3, which indicates a lack of uniformity in the indicators and dimensions used to represent organizational resilience. For example, 57\% of the studies (17 out of 30) conceptualized resilience as a multidimensional construct comprising two or three dimensions. In contrast, some studies used six or more descriptors (Brown et al., 2017; Filimonau \& De Coteau, 2019; Georgios Christos, 2017). This raises the question of validity when developing data-generating tools.

The descriptors for organizational resilience dimensions are also as varied as the studies themselves. For example, Table 3 contains 40 different dimensions of organizational resilience where adaptation/adjustment was the most recurring, representing the mode of the 
distribution and a few other dimensions common to some of the studies, including agility, anticipation, and recovery. Table 3 further reveals that most of the studies conceptualized organizational resilience both as a process and outcome. On the one hand, the process includes anticipation, sensing, planning, preparedness, and response. On the other hand, outcomes manifest in absorption, recovery, positive adaptation, transformation, and growth. Two different resilience postures were apparent from the conceptualization and operationalization of organizational resilience. These include proactive posture and reactive posture. Studies that conceptualize organizational resilience as proactive posture included anticipation, planning, and/or preparedness in their conceptual framework, and these represented the majority of the sample. By comparison, studies that conceptualized organizational resilience as reactive posture did not include disruption preparedness in their conceptualization.

\section{Discussion and Implication for Theory}

This review has established that most studies associate organizational resilience with preparedness and positive adaptation to disruptive situations. This is consistent with Barasa et al. (2018), who proposed planned resilience and adaptive resilience. This paper advances an argument that planned resilience is an enabler for adaptive resilience, and planning is necessary for positive adaptation (Bhaskar, 2018; Tracey et al., 2017; Zwane \& Kanyangale, 2019), and the lack of prior planning can undermine positive adaptation. This means that organizations that expect to be resilient to environmental disruptions must develop anticipatory and non-anticipatory planning (Duchek, 2020; Menéndez, 2018). This argument presumes that organizational resilience is both a process and an outcome in conformity with the conceptualization processes reported in Table 3. This argument is central to the advancement of resilience discourse because boundaries between resilient and non-resilient organizations are often demarcated by achieving an optimal organization-specific blend of processes, outcomes, postures, and descriptors (Mithani et al., 2020). Whether there is an industry-specific, crisis-specific, or geography-specific optimal blend of resilience metrics is a subject for another research.

Furthermore, based on the sample of studies reviewed, the review has confirmed that currently, there is no unified definition, conceptualization, and operationalization of organizational resilience in extant literature. This finding corroborates a dominant argument in the extant literature that a fully agreed and formally accepted framework for organizational resilience is yet to be figured (Edwin \& Okpara, 2015; Morales-Allende et al., 2017). This signals that knowledge production in this area is still in its nascent stages, and organizational resilience as a concept is still developing. However, its positive side is that it provides an opportunity to grow literary production in this area. 
Table 3

Conceptualization and Operationalization of Organizational Resilience

\begin{tabular}{|c|c|c|c|c|}
\hline Author(s) \& Date & Conceptualization & posture & No. & Descriptors \\
\hline Essuman et al. (2020) & Outcome & Reactive & 2 & Disruption absorption, Recoverability \\
\hline Andersson et al. (2019) & Process & Proactive & 4 & Risk awareness, cooperation, agility, improvisation \\
\hline Filimonau \& De Coteau (2019) & Process, outcome & Proactive & 7 & $\begin{array}{l}\text { Preparedness, sensing, agility, tolerance, perseverance, } \\
\text { robustness, adjustability }\end{array}$ \\
\hline Mukabi et al. (2019) & Process, outcome & Proactive & 2 & Stability, Recovery \\
\hline Suryaningtyas et al. (2019) & Process, outcome & Proactive & 4 & anticipation, preparation, response, adaptability \\
\hline Menéndez (2018) & Process, outcome & Reactive & 3 & Resistance, adaptation, learning \\
\hline Burnard et al. (2018) & Process, outcome & Proactive & 2 & Preparation, adaptation \\
\hline Jia (2018) & Outcome & Reactive & 3 & Structural capital, cognitive capital, relational capital \\
\hline Ochieng (2018) & Process, outcome & Reactive & 2 & Reactive capability, post-disruption action \\
\hline Palmi et al. (2018) & Process, outcome & Reactive & 3 & Survival, Adaptation, Growth \\
\hline Patriarca et al. (2018) & Process & & 4 & Responding, monitoring, learning, anticipating \\
\hline Prayag et al. (2018) & Process, outcome & Proactive & 2 & Planning, adaptation \\
\hline Pulungan et al. (2018) & Process & Proactive & 4 & Proactivity, adjustment of goals, Flexibility, Tolerance \\
\hline Scholarone (2018) & Process, outcome & Proactive & 4 & $\begin{array}{l}\text { Corporate responsibility, recovery, organizational learning, } \\
\text { growth }\end{array}$ \\
\hline Besuner \& Bewley (2017) & Process, outcome & & 3 & Psychological empowerment, personal resilience, leadership \\
\hline Brown et al. (2017) & Process & Proactive & 13 & $\begin{array}{l}\text { Leadership, situational awareness, innovation, proactiveness, } \\
\text { planning, strategies, clarity, breaking silos, knowledge, } \\
\text { resources, effective partnerships, decision-making, staff } \\
\text { management }\end{array}$ \\
\hline Fukofuka et al. (2017) & Process & Proactive & 4 & Openness, trust, authenticity, proaction \\
\hline Rozensky et al. (2016) & Process, outcome & Proactive & 3 & Organizational capacity, Positive adaptation, recovery \\
\hline Campos (2016) & Process, outcome & Proactive & 5 & $\begin{array}{l}\text { Institutional control, preparedness, integrity, external support, } \\
\text { communication }\end{array}$ \\
\hline Chen (2016) & Process, outcome & Reactive & 3 & Adaptability, cooperativeness, learning \\
\hline Georgios Christos (2017) & Process, outcome & Reactive & 6 & $\begin{array}{l}\text { Psychological capital, financial slack, productivity, cut-backs, } \\
\text { reevaluation, implementation }\end{array}$ \\
\hline Capano \& Woo (2017) & Outcome & Reactive & 3 & $\begin{array}{l}\text { Adaptation, resistance to external shocks, control of } \\
\text { uncertainty }\end{array}$ \\
\hline Zehir \& Narcikara (2016) & Outcome & Reactive & 3 & Hope, efficacy, optimism \\
\hline Chu (2015) & Process & Proactive & 3 & Adaptability, agility, anticipatory \& flexibility \\
\hline Collins (2015) & Process, outcome & Proactive & 3 & Sensing, seizing, transformation \\
\hline Capano \& Woo (2017) & Process, outcome & Reactive & 3 & Robustness, Agility, Integrity \\
\hline Witmer \& Mellinger, 2016 & Process & Proactive & 5 & $\begin{array}{l}\text { Focus, improvisation, reciprocity, leadership, optimism, } \\
\text { transparency }\end{array}$ \\
\hline Acosta et al. (2017) & Process, outcome & Proactive & 3 & Preparation, prevention, restoration \\
\hline
\end{tabular}

\section{A Proposed Progressive Convergent Conceptual Model}

In light of the preceding findings and discussions, this article defines organizational resilience as the process and outcome of strategic preparedness, adaptive response, and capitalizing on disruption for organizational survival, positive transformation, and prosperity. Strategic preparedness entails recognizing change as the new normal and calls for the importance of recognizing organizational resilience as a strategic issue (Annarelli \& Nonino, 2016). Preparedness is an all-encompassing concept for anticipating both the expected and the unexpected, resilience planning, monitoring, and stress-testing (Dua \& Kapur, 2018). Adaptive response entails orchestrating dynamic resource capabilities with the agility and swiftness needed to minimize the adverse effects of disruption and maximize opportunities that present themselves. The adaptive response acknowledges that disruption is not only unavoidable but also advantageous (Dahles \& Susilowati, 2015). Capitalizing on disruption entails sensing and seizing every opportunity that disruption or adversity brings along. Organizational survival is a generic term for the ability to withstand and recover from disruption (Koronis \& Ponis, 2018). Positive transformation is the progressive process and outcome of dynamic resource orchestration for enhanced market readiness in a volatile and uncertain world (Raghuramapatruni \& Kosuri, 2017). Finally, prosperity entails thriving and 
growth in adversity (Bussey, 2018). This proposed definition and conceptualization of this paper are illustrated in Figure 4.

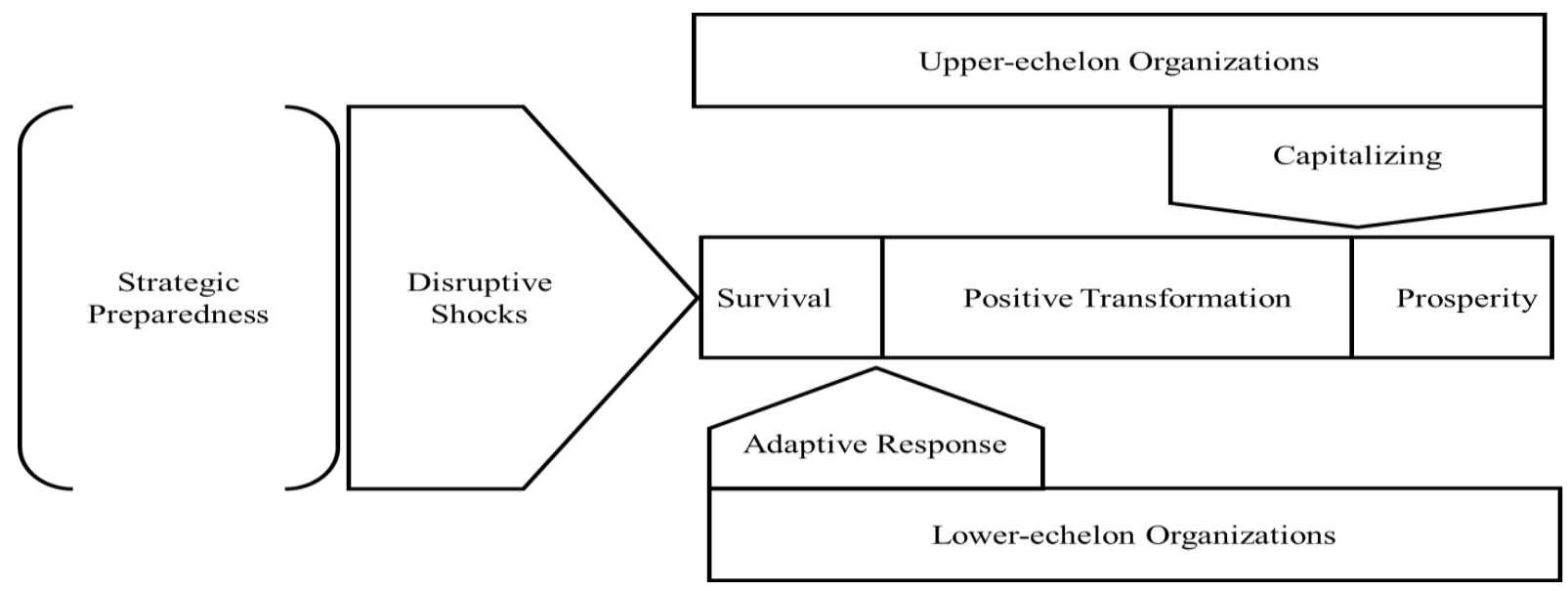

Figure 4. Conceptual model for organizational resilience

Figure 4 highlights several insights about the literature review and the ensuing conceptualization of organizational resilience. First, this article's core definition of resilience is shown in a trajectory of survival, positive transformation, and prosperity. Second, organizations achieve different resilience outcomes based on intrinsic values, preparedness, strategies, and industry characteristics (Suryaningtyas et al., 2019). This is shown by the two opposing blocks where lower-echelon organizations barely achieve survival by following the adaptive response path while upper-echelon organizations achieve prosperity by following the capitalizing path. Mid-echelon organizations lie between the two extremes and operate at an average market profile, achieving positive transformation by following a hybrid path of adaptation and capitalization. Third, the reactive and proactive postures highlighted in Table 3 serve as a metric for comparing organizations' differentiating outcomes when faced with disruptive events. For instance, at the middle of the ladder are organizations that withstand disruption with minimal or zero impact to operations but fail to seize presenting opportunities of the moment. Such organizations may not be strategic but will still be operational, potentially due to the advantage of resource slack (McCarthy et al., 2017; Saurin \& Werle, 2017). According to Saurin and Werle (2017), such organizations happen to enter the disruption phase with excess resources such as excess liquidity, cheaper inventory, cheaper credit lines, or adequate human resource. Finally, at the top of the resilience hierarchy are organizations that not only withstand disruption but were strategically positioned to transform through disruption, capitalize and prosper. These top-level organizations approach organizational resilience as a strategic issue and are prepared for both the expected and the unexpected. This rounds up the perception highlighted earlier that organizational resilience is a strategic choice in the first place.

\section{Conclusion}

This article aimed to provide a current answer to the question, what is organizational resilience? It has been demonstrated that organizational resilience as a concept is still evolving, and a unified definition is necessary to guide future scholarly works. The review has built the case for and proposed a unified definition thus: organizational resilience is both the 
process and outcome of strategic preparedness for, adaptive response to, and capitalizing on disruption for organizational survival, positive transformation, and prosperity. In a nutshell, organizational resilience can be operationalized as the product of anticipation and planning, response to disruption, shock absorption, survival and recovery from disruption, positive adaptation, and capitalizing on disruption. This has been further illustrated using a conceptual model. Thus, the article has contributed to the ongoing debate on how organizational resilience is defined and conceptualized using the most updated framework for reporting items for systematic reviews.

\section{Directions for Future Research}

Several gaps have emerged from the above analysis that calls for more research into the subject to enrich the literature and guide the development of the construct. First, one of the essential gaps relates to developing the construct as it originated from psychology and only recently expanded into organizational space. Second, there is a need for research production that models threats as an opportunity to test the resilience of organizations that grow and prosper during disruptive episodes. Third, this paper remains theoretical, and there is a need to assess some of its findings and claims empirically, particularly using challenging and real contexts such as the Covid-19 pandemic. Fourth, this systemic review revealed that most of the extant research used survey design and questionnaire instruments, while statistical analysis was performed using regression and structural equation modeling. There could be a better way of assessing resilience through the production of qualitative literature, which is currently nonexistent. Finally, currently, resilience is adopted as an all-encompassing construct. Therefore, an industry-specific, crisis-specific, or geography-specific optimal blend of resilience metrics remains a subject for further research.

\section{References}

Acosta, J., Chandra, A., \& Madrigano, J. (2017). An agenda to advance integrative resilience research and practice: Key Themes from a Resilience Roundtable. Rand Health Quarterly, 7(1), 5. https://doi.org/10.7249/rr1683

Adolph, C., Amano, K., Bang-Jensen, B., Fullman, N., \& Wilkerson, J. (2021). Pandemic politics: Timing state-level social distancing responses to COVID-19. Journal of Health Politics, Policy and Law, 46(2), 211-233. https://doi.org/10.1215/03616878-8802162

Al Balushi, M. I. A. (2020). Organizational resilience through quality management: a study on the impact of the implementation of quality management principles on resourcefulness. (Unpublished doctroal dissertation). The University of Edinburg.

Alibašić, H. (2018). Leadership strategies for embedding sustainability and resilience in organizations with an emphasis on sustainable energy. Creighton Journal of Interdisciplinary Leadership, 4(1), 17-26. https://doi.org/10.17062/cjil.v4i1.63

Andersson, T., Cäker, M., Tengblad, S., \& Wickelgren, M. (2019). Building traits for organizational resilience through balancing organizational structures. Scandinavian Journal of Management, 35(1), 36-45. https://doi.org/10.1016/j.scaman.2019.01.001

Annarelli, A., \& Nonino, F. (2016). Strategic and operational management of organizational resilience: Current state of research and future directions. Omega, 62, 1-18. https://doi.org/10.1016/j.omega.2015.08.004

Bakshi, V. (2017). The Forward-Looking manager in a VUCA world. Sage Publishing India.

Barasa, E., Mbau, R., \& Gilson, L. (2018). What is resilience and how can it be nurtured? A systematic review of empirical literature on organizational resilience. International Journal of Health Policy and Management, 7(6), 491-503. https://doi.org/10.15171/ijhpm.2018.06

Besuner, P., \& Bewley, L. (2017). Leadership attributes and behaviors as predictors of organizational resilience in academic health care systems. International Journal of Economics, Business and Management Research, 1(2), 167-188. 
Bhaskar, P. R. (2018). Managing unexpected disruptions: The resilience of shipping companies. (Doctoral dissertation). University of Tasmania.

Brown, C., Seville, E., \& Vargo, J. (2017). Measuring the organizational resilience of critical infrastructure providers: A New Zealand case study. International Journal of Critical Infrastructure Protection, 18, 37-49. https://doi.org/10.1016/j.ijcip.2017.05.002

Burnard, K., Bhamra, R., \& Tsinopoulos, C. (2018). Building organizational resilience: Four configurations. IEEE Transactions on Engineering Management, 65(3), 351-362. https://doi.org/10.1109/tem.2018.2796181

Bussey, S. E. S. (2018). Thriving the adversity: The organizational strategy that transformed a city. Journal of Biblical Perspectives in Leadership, 8(1), 114-125.

Campos, K. P. (2016). Dimensions of business resilience in the context of post-disaster recovery in Davao City, Philippines. Review of Integrative Business \& Economics, 2(1), 168-198.

Capano, G., \& Woo, J. J. (2017). Resilience and robustness in policy design: a critical appraisal. Policy Sciences, 50(3), 399-426. https://doi.org/10.1007/s11077-016-9273-

Chakrabarti, A. (2015). Organizational adaptation in an economic shock: The role of growth reconfiguration. Strategic Management Journal, 36(11), 1717-1738.

Chen, S. h. (2016). Construction of an early risk warning model of organizational resilience: An empirical study based on samples of R\&D Teams. Discrete Dynamics in Nature and Society, 2016, 1-9. https://doi.org/10.1155/2016/4602870

Chu, Y. H. (2015). Resilience capabilities in the face of environmental turbulence: the case of Hong Kong small to medium enterprises (Unpublished doctoral dissertation). RMIT University.

Collins, S. (2015). Strategizing for resilience. (Unpublished doctoral dissertation). Victoria University of Wellington.

Dahles, H., \& Susilowati, T. P. (2015). Business resilience in times of growth and crisis. Annals of Tourism Research, 51 , 34-50. https://doi.org/10.1016/j.annals.2015.01.002

Danziger, R., \& Kampf, Z. (2020). Interpretive constructs in contrast: The case of flattery in Hebrew and in Palestinian Arabic. Contrastive Pragmatics, 1(aop), 1-31.

Di Gennaro, F., Pizzol, D., Marotta, C., Antunes, M., Racalbuto, V., Veronese, N., \& Smith, L. (2020). Coronavirus Diseases (COVID-19) Current status and future perspectives: A narrative review. International Journal of Environmental Research and Public Health, 17(8), 1-11. https://doi.org/10.3390/ijerph17082690

Doğantan, E., \& Kozak, M. (2019). Resilience capacity in different types of tourism businesses. Tourism: An International Interdisciplinary Journal, 67(2), 126-146. https://doi.org/10.1007/978-3-319-01669-6_279-1

Dua, P., \& Kapur, H. (2018). Macro stress testing and resilience assessment of Indian banking. Journal of Policy Modeling, 40(2), 452-475. https://doi.org/10.1016/j.jpolmod.2018.01.005

Duchek, S. (2020). Organizational resilience: a capability-based conceptualization. Business Research, 13(1), 215-246. https://doi.org/10.1007/s40685-019-0085-7

Duchene, D. (2017). Sustainable leadership: How to lead in a VUCA world. Belgium: Die Keure Publishing.

Edwin, A., \& Okpara, A. (2015). Strategic review of the impact of globalization on the sustainability of communities and business organizations. International Journal of Business and Management Invention, 4(4), 55-62.

Essuman, D., Boso, N., \& Annan, J. (2020). Operational resilience, disruption, and efficiency: Conceptual and empirical analyses. International Journal of Production Economics, 229, 107762. https://doi.org/10.1016/j.ijpe.2020.107762

Filimonau, V., \& De Coteau, D. (2019). Tourism resilience in the context of integrated destination and disaster management. International Journal of Tourism Research, 1-21

Fukofuka, S., Fukofuka, P. T., \& Loke, D. T. (2017). Predictors of organizational resilience: A path analysis. Global Journal of Human Resource Management, 5(9), 31-42.

Georgios Christos, G. (2017). Organizational resilience: how some manage to survive where others fail in the context of the Greek tourism sector (Master's thesis). International Hellenic University. http://hdl.handle.net/11544/15228

Gephart, R. P. (2018). Qualitative research as interpretive social science. The Sage Handbook of Qualitative Business and Management Research Methods, 33-53.

Gorzeń-Mitka, I. (2016). Shaping organizational resilience in an unstable world: Possibility or necessity? Problems of Management in the 21 st Century, 11(2), 68-70. https://doi.org/10.33225/pmc/16.11.68

Harzing, A. (2010). The Publish or Perish book: Your guide to effective and responsible citation analysis. Melbourne: Tarma Software Research Pty Ltd.

Holbeche, L. (2015). The Agile Organization: How to build an innovative, sustainable and resilient business. Kogan Page Publishers. 
Ince, H., Imamoglu, S. Z., Karakose, M. A., \& Turkcan, H. (2017). The search for understanding organizational resilience. The European Proceedings of Social \& Behavioral Sciences, 230-243. https://doi.org/10.15405/epsbs.2017.12.02.20

Jia, X. (2018). The role of social capital in building organizational resilience (Unpublished master's thesis). University of Canterbury.

Kok, J., \& Van den Heuvel, S. C. (2018). Leading in a VUCA world: Integrating leadership, discernment and spirituality. New York, NY: Springer.

Koronis, E., \& Ponis, S. (2018). Better than before: the resilient organization in crisis mode. Journal of Business Strategy, 39(1), 32-42. https://doi.org/10.1108/jbs-10-2016-0124

Lund, R., \& Blaikie, P. (Eds.). (2013). The Tsunami of 2004 in Sri Lanka: Impacts and policy in the shadow of civil war. Routledge.

Ma, Z., Xiao, L., \& Yin, J. (2018). Toward a dynamic model of organizational resilience. Nankai Business Review International, 9(3), 246-263. https://doi.org/10.1108/nbri-07-2017-0041

Mack, O., Khare, A., Kramer, A., \& Burgartz, T. (2015). Managing in a VUCA world. New York, NY: Springer.

McCarthy, I. P., Collard, M., \& Johnson, M. (2017). Adaptive organizational resilience: an evolutionary perspective. Current Opinion in Environmental Sustainability, 28, 33-40. https://doi.org/10.1016/j.cosust.2017.07.005

Menéndez, J. M. (2018). Organizational Resilience. How Learning Sustains Organizations in Crisis, Disaster, and Breakdown by D. Christopher Kayes. The Learning Organization, 25(2), 143-146. https://doi.org/10.1108/tlo-07-20170074

Misra, D. P., \& Agarwal, V. (2018). Systematic Reviews: Challenges for their justification, related comprehensive searches, and implications. Journal of Korean Medical Science, 33(12), 1-9. https://doi.org/10.3346/jkms.2018.33.e92

Mithani, M. A., Gopalakrishnan, S., \& Santoro, M. D. (2020). Does exposure to a traumatic event make organizations resilient? Long Range Planning, 54(3), 102031.

Morales-Allende, M., Ruiz-Martin, C., Lopez-Paredes, A., \& Perez-Ríos, J. M. (2017). Aligning organizational pathologies and organizational resilience indicators. International Journal of Production Management and Engineering, 5(2), 107116. https://doi.org/10.4995/ijpme.2017.7423

Mukabi, M. W., Marwa, S. M., \& Kiragu, D. N. (2019) Crisis management strategies for the attainment of business continuity management best practices. Global Scientific Journals, 7(2), 791-807.

Njiforti, P. (2015). Impact of the 2007/2008 global financial crisis on the stock market in Nigeria. Journal of Applied Statistics, 6(1), 49-68.

Ochieng, A. O. (2018). Supply chain resilience and organizational performance of pharmaceutical manufacturing companies in Nairobi (Unpublished master's thesis). University of Nairobi.

Padar, K., \& Pataki, B. (2018). What lies behind the concept of organizational resilience and related concepts? An analytical literature review. Economics Questions, Issues and Problems, 7(4), 280-286. Retrieved from www.irisro.org

Page, M. J., McKenzie, J. E., Bossuyt, P. M., Boutron, I., Hoffmann, T. C., Mulrow, C. D., Shamseer, L., Tetzlaff, J. M., Akl, E. A., Brennan, S. E., Chou, R., Glanville, J., Grimshaw, J. M., Hróbjartsson, A., Lalu, M. M., Li, T., Loder, E. W., Mayo-Wilson, E., McDonald, S., ... Moher, D. (2021). The PRISMA 2020 statement: An updated guideline for reporting systematic reviews. PLOS Medicine, 18(3), e1003583. https://doi.org/10.1371/journal.pmed.1003583

Palmi, P., Morrone, D., Paolo Miglietta, P., \& Fusco, G. (2018). How did organizational resilience work before and after the financial crisis? An empirical study. International Journal of Business and Management, 13(10), 54-62. https://doi.org/10.5539/ijbm.v13n10p54

Panhwar, A. H., Ansari, S., \& Shah, A. A. (2017). Post-positivism: An effective paradigm for social and educational research. International Research Journal of Arts \& Humanities (IRJAH), 45(45).

Pariès, J. (2017). Complexity, emergence, resilience. In E. Hollnagel, D. D. Woods, \& N. Leveson (Eds.), Resilience Engineering: Concepts and Precepts (pp. 43-53). Farnham, UK: Ashgate Publishing Limited.

Patriarca, R., Di Gravio, G., Costantino, F., Falegnami, A., \& Bilotta, F. (2018). An analytic framework to assess organizational resilience. Safety and Health at Work, 9(3), 265-276. https://doi.org/10.1016/j.shaw.2017.10.005

Prayag, G., Chowdhury, M., Spector, S., \& Orchiston, C. (2018). Organizational resilience and financial performance. Annals of Tourism Research, 73, 193-196. https://doi.org/10.1016/j.annals.2018.06.006

Pulungan, S., Daihani, D. U., \& Arafah, W. (2018). The influence of firm strategy and organizational resilience to technology orientation and its implications to company performance of coal mining company in Indonesia. International Journal of Business and Management Invention, 62-73

Raghuramapatruni, R., \& Kosuri, S. (2017). The straits of success in a VUCA world. IOSR Journal of Business and Management, 19, 16-22. 
Rozensky, R. H., Sher, K. J., Lori, C., Westfeld, J. S., \& Gutierrez, P. L. (2016). Organizational Challenges, Resilience, and Healing: 2016 Annual Report of the Policy and Planning Board. Retrieved from The American Psychological Association's (APA) Bylaws Article XI.7

Ruiz-Martin, C., Lopez-Paredes, A., \& Wainer, G. (2018). What we know and do not know about organizational resilience. International Journal of Production Management and Engineering, 6(1), 11-28. doi:10.4995/ijpme.2018.7898

Ruiz-Martin, C., Pérez Rios, J. M., Wainer, G., Pajares, J., Hernández, C., \& López-Paredes, A. (2017). The application of the viable system model to enhance organizational resilience. Lecture Notes in Management and Industrial Engineering, 95-107. https://doi.org/10.1007/978-3-319-55889-9_5

Saurin, T. A., \& Werle, N. J. (2017). A framework for the analysis of slack in socio-technical systems. Reliability Engineering \& System Safety, 167, 439-451.

Sawyerr, E., \& Harrison, C. (2019). Developing resilient supply chains: lessons from high-reliability organisations. Supply Chain Management: An International Journal, 25(1), 77-100. https://doi.org/10.1108/scm-09-2018-0329

Scholarone, M. (2018). How to emerge stronger: Antecedents and consequences of organizational resilience. Journal of Management \& Organization, 1-45.

Selcuk, A. A. (2019). A guide for systematic reviews: PRISMA. Turk Arch Otorhinolaryngol, 57(1), 57-8.

Serhun, Al. (2013). Interpretive research design: concepts and processes. International Journal of Social Research Methodology, 16(4), 351352. https://doi.org/10.1080/13645579.2013.802464

Siddaway, A. P., Wood, A. M., \& Hedges, L. V. (2019). How to do a systematic review: A best practice guide to conducting and reporting narrative reviews, meta-analyses, and meta-syntheses. Annual Review of Psychology, 70(1), 150 .

Smith, M., \& Zeigler, S. M. (2017). Terrorism before and after 9/11 - a more dangerous world? Research and Politics, 1-8.

Snyder, H. (2019). Literature review as a research methodology: An overview and guidelines. Journal of Business Research, 104(2019), 333-339.

Suryaningtyas, D., Sudiro, A., Troena, E. A., \& Irawanto, D. W. (2019). Organizational resilience and organizational performance: examining the mediating roles of resilient leadership and organizational culture. Academy of Strategic Management Journal, 18(2), 1-7.

Tracey, S., O'Sullivan, T. L., Lane, D. E., Guy, E., \& Courtemanche, J. (2017). Promoting resilience using an asset-based approach to business continuity planning. SAGE Open, 7(2). https://doi.org/10.1177/2158244017706712

Wishart, M. (2018). Business resilience in an SME context: A literature review. Birmingham, UK, Warwick Business School: Enterprise Research Center.

Witmer, H., \& Mellinger, M. S. (2016, May 24). Organizational resilience: Nonprofit organizations' response to change. Work, 54(2), 255-265. https://doi.org/10.3233/WOR-162303

Yang, X. (2019). Unraveling the meaning and measurement of organizational resilience. (Unpublished doctoral dissertation). RMIT University.

Zehir, C., \& Narckkara, E. (2016). Effects of resilience on productivity under authentic leadership. Procedia - Social and Behavioral Sciences, 235, 250-258. https://doi.org/10.1016/j.sbspro.2016.11.021

Zwane, M., \& Kanyangale, M. (2019). Shaping the organizational architecture for SME survival: A case of nascent small restaurants in Durban. African Journal of Hospitality, Tourism and Leisure, 8(4), 1-17.

\section{Acknowledgements}

Not applicable.

\section{Disclosure Statement}

No potential conflict of interest was reported by the authors.

\section{Funding Acknowledgements}

Not applicable.

\section{Open Access}

The International Journal of Organizational Leadership publishes open access articles under the terms of the Creative Commons Attribution (CC BY) License, which permits use, distribution, and reproduction in any medium, provided the original work is properly cited. 